ACTA UNIVERSITATIS WRATISLAVIENSIS

PRZEGLĄD PRAWA I ADMINISTRACJI CXX/2

WROCŁAW 2020

https://doi.org/10.19195/0137-1134.120.103

\author{
MATEUSZ SZYMURA \\ ORCID: 0000-0001-7146-8477 \\ Uniwersytet Wrocławski \\ Instytut Historii Państwa i Prawa \\ Zakład Prawa Rzymskiego
}

\title{
GENEZA JURYSDYKCJI APELACYJNEJ IZBY LORDÓW NAD ROZSTRZYGNIĘCIAMI SĄDÓW SZKOCKICH
}

\begin{abstract}
Abstrakt: W opracowaniu autor podejmuje próbę przedstawienia genezy i rozwoju jurysdykcji apelacyjnej wyższej izby parlamentu brytyjskiego, jaką jest Izba Lordów. Analiza koncentruje się na przedstawieniu źródeł i zakresu uprawnień sądowniczych posiadanych przez parlamenty królestw, które weszły w skład Zjednoczonego Królestwa Wielkiej Brytanii, a następnie dyskusji i rozwiązań, które stały u podstaw regulacji relacji obu systemów prawnych w traktacie zjednoczeniowym z 1707 roku. Ostatnią częścią analizy jest przedstawienie najważniejszych aspektów sprawowania jurysdykcji apelacyjnej przez Izbę Lordów w okresie do powstania Sądu Najwyższego Zjednoczonego Królestwa.
\end{abstract}

Słowa kluczowe: prawo szkockie, Sąd Sesji, Izba Lordów, hybrydowe systemy prawne

\section{WPROWADZENIE}

Dnia 1 października 2009 roku w pewien symboliczny sposób ${ }^{1}$ doszło do usunięcia $\mathrm{z}$ brytyjskiego systemu prawnego znaczącego odstępstwa od zasady trójpodziału władzy, które to odstępstwo związane było z posiadaniem uprawnień sądowniczych przez organy dwóch pozostałych władz - wykonawczej, w postaci Komitetu Sądowniczego Tajnej Rady (Judicial Committee of the Privy Council) oraz ustawodawczej, w postaci uprawnień jurysdykcyjnych wyższej izby brytyjskiego Parlamentu - Izby Lordów.

Przedmiotem niniejszego opracowania jest próba ukazania kształtowania się jurysdykcji drugiego z tych organów. Z uwagi na to, że obecny kształt rozwiązań konstytucyjnych Zjednoczonego Królestwa jest wynikiem treści traktatu zjed-

${ }^{1}$ Na skutek wejścia w życie ustawy Constitutional Reform Act z 2005 roku (2005, c. 4) i utworzenia Sądu Najwyższego Zjednoczonego Królestwa (Supreme Court of the United Kingdom), http:// www.legislation.gov.uk/ukpga/2005/4/contents (dostęp: 4.02.2020). 
noczeniowego ${ }^{2}$ z 1707 roku $^{3}$, konieczne będzie przedstawienie genezy uprawnień sądowniczych parlamentów szkockiego i angielskiego do końca XVIII wieku, sposób ukształtowania tej jurysdykcji w ramach Zjednoczonego Królestwa oraz wpływ tych rozwiązań na kształt i charakter szkockiego systemu prawnego, szczególnie względem gwarancji jego niezależności wynikającej z traktatu z 1707 roku.

Swoje rozważania ograniczę w głównej mierze do jurysdykcji Izby Lordów w zakresie rozpoznawania odwołań od wyroków Sądu Sesji. Ograniczenie to wynika z kilku względów. W pierwszym rzędzie kwestia jurysdykcji Izby Lordów w sprawach angielskich i irlandzkich (a dawniej również kolonialnych) nigdy nie budziła szczególnej wątpliwości. Ograniczenie wywodu jedynie do spraw cywilnych jest konsekwencją ciekawej anomalii historycznej, ponieważ — mimo istnienia przed unią dwóch szkockich sądów najwyższych ${ }^{4}$ — tylko w wypadku orzeczeń Sądu Sesji przysługiwało odwołanie do szkockiego sądu parlamentarnego ${ }^{5}$ i też jedynie w tym zakresie doszło do przeniesienia uprawnień na wyższą izbę brytyjskiego parlamentu.

Samo zaś pytanie o ostateczną instancję odwoławczą nie stanowi jedynie rozważań nad istotnym problemem jurysdykcyjnym, ale — wobec hybrydowego charakteru szkockiego systemu praw prywatnego — natura najwyższego organu sądowego nie pozostaje bez znaczenia dla systemu balansującego między próbą ochrony rodzimego pierwiastka cywilistycznego a coraz dalej idącą harmonizacją $\mathrm{z}$ wiodącą anglosaską tradycją prawną ${ }^{6}$.

2 Autor niniejszego opracowania konsekwentnie posługuje się tym sformułowaniem na określenie ustaw angielskich i szkockich, których wynikiem było powstanie Zjednoczonego Królestwa Wielkiej Brytanii, przede wszystkim dla odróżnienia ich od tworzonego w XX oraz XXI wieku przepisów prawa unijnego.

3 Union with England Act 1707 (1707, c. 7), http://www.legislation.gov.uk/aosp/1707/7/contents (dostęp: 4.02.2020).

${ }^{4}$ Rozpoznającego sprawy cywilne Sądu Sesji (Court of Session) oraz rozpoznającego sprawy karne Wysokiego Sądu Justyciariusza (High Court of Justiciary). Później do tej godności wyniesiono sąd morski (High Court of Admirality) oraz nowo utworzony sąd zajmujący się podatkami i cłami - Court of Exchequer.

5 A. Page, Final appellate jurisdiction in the scottish legal system: The end of the anomaly, „Edinburgh Law Review” 2010, nr 2, s. 269.

${ }^{6}$ W sposób wyraźny na zagrożenie anglicyzacji prawa szkockiego w drodze orzecznictwa Izby Lordów wskazują: P. du Plessis, The promises and pitfalls of mixed legal systems: the South African and Scottish experiences, „Stellenbosch Law Review” 338, 1998; R. Evans-Jones, Receptions of law, mixed legal systems and the myth of the genius of Scots private law, „Law Quarterly Review” 114, 1998; E. Örücü, Judge and jurist in Scotland: On the verge of a second renaissance, „Tulane Law Review" 78, 2003-2004; K. Reid, R. Zimmermann, A History of Private Law in Scotland: Introduction and property, Oxford 2000; W. Tetley, Mixed jurisdictions: Common law v. Civil law (codified and uncodified), „Louisiana Law Review” 3, 2000. 


\section{GENEZA JURYSDYKCJI SĄDU PARLAMENTARNEGO W KRÓLESTWIE SZKOCJI}

Historycznym źródłem jurysdykcji szkockiego parlamentu było przekonanie, że najwyższym źródłem sprawiedliwości jest król, do którego zawsze można było skierować skargę w przypadku błędu lub niesprawiedliwego orzeczenia. Mnogość funkcji panującego sprawiła, że uprawnienie do słuchania stanowisk stron i rozstrzygania w jego imieniu została przez niego scedowana na zgromadzenie stanowe ${ }^{7}$, a estyma, jaką cieszył się Sąd Sesji, sprawiła, że sprawy te zdarzały się wyjątkowo rzadko.

Jurysdykcja szkockiego parlamentu została zakwestionowana niedługo przed Unią na skutek wniesienia odwołania pozwanego w sprawie Dunfermline vs. Callendar z 1674 roku. Powód, protestując przeciwko takiemu środkowi odwoławczemu, przekonał króla do zagrożenia wydaleniem z zawodu każdemu adwokatowi, który ośmieliłby się na wniesienie podobnego środka zaskarżenia ${ }^{8}$. Sankcja ta spotkała około 50 edynburskich adwokatów, którym dodatkowo nakazano opuścić stolicę? Efektem tych działań było faktyczne sparaliżowanie szkockiego sądownictwa między 1674 a 1676 rokiem do tego stopnia, iż odbiło się to na obrocie handlowym ${ }^{10}$.

Wskazuje się, że jednym z głównych przeciwników uprawnień sądowniczych parlamentu był król Jakub II Stuart, który widział w tym ograniczenie swojej władzy królewskiej, jak miało to miejsce w drugim z królestw, w których panował. Wraz z detronizacją jego następcy kwestia jurysdykcji odwoławczej szkockiego parlamentu stała się przedmiotem ponownej debaty ${ }^{11}$. Wstępujący na tron w miejsce zdetronizowanego ojca Maria Stuart wraz ze swoim mężem Wilhelmem Orańskim w specjalnej ustawie regulującej zasady ich panowania ${ }^{12}$ potwierdzili uprawnienia sądownicze szkockiego parlamentu ${ }^{13}$ przy zastrzeżeniu, że rozpoznawanie sprawy przez parlament nie będzie prowadzić do wstrzymania wykonalności wyroku Sądu Sesji ${ }^{14}$. Jednocześnie ten środek odwoławczy nie cieszył się specjalną popularnością — w okresie między 1689 a 1707 rokiem z tego prawa skorzystano jedynie sześć razy ${ }^{15}$.

7 The supreme appellate jurisdiction, „Monthly Law Magazine” 1841, nr 39, s. 154.

8 C.A. Malcolm, House of Lords and appeals form Scotland, „Juridical Review” 1910-1911, nr 4, s. 297.

9 A.J. MacLean, The 1707 union: Scots law and the house of lords, „The Journal of Legal History" 1984, nr 4, s. 63

${ }^{10}$ Kryzys ten zbiegł się w czasie ze sporami jurysdykcyjnymi w Anglii, gdzie sędziowie sądów kanclerskich oraz dwóch najwyższych sądów common law (King's Bench oraz Common Pleas) kwestionowali jurysdykcje Izby Lordów. C.A. Malcolm, op. cit., s. 298.

11 T. Beven, Appellate jurisdiction of the House of Lords II, „Law Quarterly Review” 1901, nr 4, s. 362-363.

12 Claim of Right Act, c. 28, 1689, http://www.legislation.gov.uk/aosp/1689/28/contents (dostęp: 4.02.2020).

13 C.A. Malcolm, op. cit., s. 295.

14 A.J. MacLean., op. cit., s. 63.

15 C.A. Malcolm, op. cit., s. 298. 
Podsumowując rozważania w tym zakresie, wypada stwierdzić, że uprawnienia sądownicze szkockiego parlamentu w momencie unii z Anglią nie budziły żadnej wątpliwości ${ }^{16}$.

\section{GENEZA JURYSDYKCJI ANGIELSKIEJ IZBY LORDÓW}

Również w Anglii króla uznawano za źródło sprawiedliwości, a jego wola stanowić miała źródło jurysdykcji innych organów sądowych. Potwierdzają to Ranulf z Glanvill ${ }^{17}$, Henry Bracton ${ }^{18}$ oraz William Blackstone ${ }^{19}$. Jednocześnie samo sprawowanie wymiaru sprawiedliwości uznawano zarówno za prerogatywę królewską, jak i za źródło dochodu panującego ${ }^{20}$.

MacLean wskazuje, że już królowie germańskich królestw heptarchicznych sprawowali wymiar sprawiedliwości w obecności dostojników dworskich ${ }^{21}$. Z kolei Breven uprawnień jurysdykcyjnych Izby Lordów upatruje w zmianach, jakie zaszły we wczesnoangielskim społeczeństwie na skutek podboju Wilhelma Zdobywcy, który osadzając na ważnych stanowiskach podległych sobie możnowładców normańskich, sprowadził do Anglii znane na kontynencie mechanizmy prawa feudalnego z szerokimi uprawnieniami jurysdykcyjnymi możnowładców wobec podległej im ludności. Król, starając się powiększyć zakres swojej władzy, dążył do ograniczania uprawnień sądowych innych podmiotów — z przyczyn prestiżowych $^{22}$ i fiskalnych ${ }^{23}$.

16 Kwestia odwołań stała się również przedmiotem debaty przywróconego w 1999 roku w skutek dewolucji uprawnień szkockiego Parlamentu, który jednak uznał, że kwestie te leżą poza zakresem jego kognicji. A. Page, op. cit., s. 269.

17 Tractatus de legibus et conseutudinibus regni Anglie, Londyn 1188, księga 12, rozdział I - Glanvill wskazuje, że niektóre sprawy wprost podlegają pod sąd królewski, inne muszą być rozpoznane najpierw przez niższe sądy, jednak król zawsze ma uprawnienie do wywołania sprawy do rozpoznania przez siebie.

18 De Legibus et Consuetudinibus Angliae, Londyn 1569, księga III, s. 107.

19 Commentaries on the Laws of England, Londyn 1765, księga I, s. 267.

20 T. Beven, Appellate jurisdiction of the House of Lords, „Law Quarterly Review” 1901, nr 2, s. 155.

${ }^{21}$ Nawet po przejęciu faktycznego sprawowania wymiaru sprawiedliwości przez Izbę Lordów, która orzekała bez udziału króla, uznawano to uprawnienie jedną z prerogatyw władcy (King-in-Parliament). A.J. MacLean, op. cit., s. 50.

${ }^{22}$ Zazdrość króla, a może także w pewnym stopniu strach przed niezależnością jego najpotężniejszych poddanych, prowadził do ciągłego ograniczania zakresu kognicji sądów szlacheckich (baronial courts) oraz wiejskich (manorial courts), a także powstania systemu środków odwoławczych od tych orzeczeń, w szczególności do sądów hrabstw (county courts), które pozostawały pod kontrolą królewskich urzędników. T. Beven, Appellate jurisdiction of the House of Lords..., s. 156.

23 Sąd królewski nie posiadał przy tym wyłącznej jurysdykcji, jednak każda sprawa mogła po odpowiedniej - często wynoszącej nawet jedną trzecią wartości sporu — opłacie być przeniesiona do rozstrzygnięcia przed nim. T. Beven, Appellate jurisdiction of the House of Lords..., s. 157-158. 
Wraz z wykształceniem się dwóch Izb angielskiego parlamentu w XIV wieku do każdej z nich można było kierować petycje o rozsądzenie sporu. W XV wieku utrwaliła się zasada, że decyzje Izby Gmin wymagają zatwierdzenia przez Izbę Lordów, jednak ów proces nie działał w drugą stronę. To dało początek przyznania uprawnień jurysdykcyjnych jedynie wyższej z Izb. Wiek XVI to z kolei okres małej aktywności sądu parlamentarnego, co prawdopodobnie wynikało z lepszego poziomu orzecznictwa najwyższych sądów królestwa ${ }^{24}$.

Zakres jurysdykcji Izby Lordów ulegał stopniowemu rozszerzaniu. Początkowo uprawnienia Izby Lordów był związane ze sprawami parów, zgodnie z regułą jury of peers — wraz z wyodrębnieniem członków parlamentu jako osobnego stanu społecznego jedynie spośród tego gremium można było wybierać sędziów na potrzeby postępowań dotyczących członków parlamentu. Kolejnym krokiem rozszerzenia jurysdykcji był tak zwany writ of error, który umożliwiał odwołanie na podstawie błędu co do prawa od wyroków najwyższych sądów angielskich tak, aby Parlament mógł naprawić powstały błąd ${ }^{25}$.

W sprawach rozpoznawanych przez Sądy Kanclerskie początkowo nie istniało prawo do kontroli instancyjnej orzeczeń. Strony niezadowolone z orzeczenia mogły domagać się zmiany wyroku przez króla, który rozpoznawanie takich spraw przekazywał do kognicji powoływanych ad hoc komisji składających się z niektórych członków rady królewskiej ${ }^{26}$. Przełom nastąpił w sprawie Matthews vs. Matthews, zakończonej prawomocnym wyrokiem w 1624 roku, od którego strona przegrana starała się odwołać do Izby Lordów. Petycja nie doprowadziła do skierowania sprawy na wokandę parlamentarną, jednak Izba nakazała ponowne rozpoznanie sprawy przez sąd kanclerski ${ }^{27}$.

Okres ostatniego półwiecza poprzedzającego unię ze Szkocją stał się polem walki obu Izb o uzyskanie nadrzędnej pozycji sądowniczej. Pierwszy kryzys wynikł na tle sprawy z powództwa Thomasa Skinnera przeciwko Kompanii Wschodnioindyjskiej ${ }^{28}$. W wyniku nierozwiązanego w drodze arbitrażu sporu handlowego powód wniósł skargę do Izby Lordów. Pozwana, której nakazano udzielić odpowiedzi na zarzuty powoda, zwróciła się do Izby Gmin, wskazując na nadzwyczajny charakter skargi Skinnera, która nie była skargą na wyrok niższego sądu, a pozwem skierowanym bezpośrednio do Izby Lordów. Izba Gmin, której część członków zainwestowała znaczne środki w Kompanię, podjęła uchwałę potępiającą Skinnera i weszła w bezpośredni spór z Izbą Lordów, który trwał do 1670 roku, gdy król nakazał obu Izbom zaprzestanie rozpoznawania sprawy, co ostatecznie ograniczyło jurysdykcję

${ }^{24}$ Nieuregulowanie tej kwestii i wytworzenie się zwyczaju było przez niektórych uznawane za uzurpację tego uprawnienia. The supreme appellate..., s. 153.

${ }^{25}$ T. Beven, Appellate jurisdiction of the House of Lords ..., s. 162.

26 Ibidem, s. 164.

27 Ibidem, s. 165.

28 Skinner v. East India Company, 1666, St. Tr. 710. 
Izby Lordów do spraw odwoławczych ${ }^{29}$. Kolejne dwa kryzysy ${ }^{30}$ wynikały z próby zakwestionowania uprawnień Izby Lordów do rozpoznawania odwołań od sądów orzekających na podstawie equity (w szczególności Sądów Kanclerskich) — jednak zakres jurysdykcji angielskiej Izby Lordów nie uległ już zmianie ${ }^{31}$.

\section{TRAKTAT ZJEDNOCZENIOWY Z 1707 ROKU ${ }^{32}$ A ISTNIENIE KOGNICJI SĄDU PARLAMENTARNEGO}

Gdy w 1603 roku Jakub VI zasiadł na tronie angielskim, królestwa zaczęła łączyć unia personalna, jednak oba królestwa i ich organy pozostały odrębne. Parlamenty obu królestw wykonywały własne uprawnienia sądowe ${ }^{33}$.

Sytuacja zmieniła się w 1707 roku wraz z wejściem w życie angielskiej i szkockiej ustawy ratyfikującej unię realną i powstaniem Zjednoczonego Królestwa Wielkiej Brytanii. Oba królestwa miały odmienne struktury organów przedstawicielskich — unikameralny szkocki parlament, w którym zasiadali przedstawiciele czterech stanów ${ }^{34}$, oraz bikameralny angielski parlament składający się z Izby Gmin oraz Izby Lordów. Nowy brytyjski parlament przyjął model angielski, a w Izbie Lordów zasiadło szesnastu szkockich parów ${ }^{35}$.

Szkoccy pisarze instytucjonalni, opisując skutki traktatu, widzieli w nim zapewnienie ciągłości konstytucyjnej instytucji państwowych. Bankton opisywał traktat jako formę przeniesienia suwerennej władzy z poziomu obu królestw na nowe organy zjednoczonego królestwa ${ }^{36}$, Erskine zaś uznawał brytyjski parlament za następcę szkockiego we wszystkich uprawnieniach dawnego organu ${ }^{37}$.

Sytuacja unii realnej na nowo otworzyła dyskusję nad koniecznością utrzymania jurysdykcji odwoławczej sądu parlamentarnego oraz ewentualnymi alternatywami dla takiego rozwiązania. Page, opisując możliwe rozwiązania, jako pierwsze wskazuje utworzenie dla Szkocji autonomicznego systemu sądowego. Jednocześnie zauważa, że w jego ocenie ten model jest niemożliwy do zastosowania bez uzyskania niepodległości i wprowadzenia niezależnego sądu konstytu-

29 G. Dymond, The Appelate Jurisdiction of the House of Lords, s. 4, http://researchbriefings. files.parliament.uk/documents/LLN-2009-010/LLN-2009-010.pdf (dostęp: 4.02.2020).

30 Sprawy Shirley vs. Fagg z 1675 roku oraz Ashby vs. White z 1703 roku.

31 G. Dymond, op.cit., s. 4.

32 Union with England Act 1707, c. 7, http://www.legislation.gov.uk/aosp/1707/7/contents (dostęp: 4.02.2020).

33 A.J. MacLean., op. cit., s. 60.

34 Duchowieństwa, szlachty, mieszczaństwa oraz przedstawicieli hrabstw.

35 A.J. MacLean., op. cit., s. 50.

36 A. MacDouall, Lord Bankton, An Institute of the Laws of Scotland, 4, 1753, s. 452, tytuł 1, fragment 16 .

37 J. Erskine, Principles of the Law of Scotland, 1, 1816, s. 24, tytuł 3, fragment 4. 
cyjnego $^{38}$. Drugim modelem byłaby unifikacja, czyli wprowadzenie możliwości odwoływania się do Izby Lordów także w sprawach karnych, czego jednak nikt ani po stronie angielskiej, ani tym bardziej szkockiej nie postuluje ${ }^{39}$. Model trzeci zakłada zachowanie status quo poprzez pozostawienie oddzielnej ścieżki odwoławczej w sprawach cywilnych i sprawach karnych, jednak z modyfikacjami w zakresie roli najwyższej instancji — od wprowadzenia sądowej Izby Szkockiej, w której zasiadaliby prawnicy będący znawcami tego systemu prawnego, lub przekształcenia Izby Lordów w instytucję na wzór Europejskiego Trybunału Sprawiedliwości, która funkcjonowałaby w pewnej symbiozie z najwyższymi sądami królestw, działając w oparciu o mechanizm podobny do pytań prejudycjalnych ${ }^{40}$.

Z punktu widzenia ochrony odrębności szkockiego systemu prawnego kluczowe stały się dwa artykuły. Artykuł 18 wprowadzał zasadę ochrony prawa prywatnego, które nie mogło być zmieniane bez zgody Szkotów, oraz zakładał unifikację przepisów w zakresu handlu, ceł oraz szeroko rozumianego prawa publicznego ${ }^{41}$. Z kolei artykuł 19 regulował — z jednej strony — ochronę szkockiego systemu sądowego z Sądem Sesji na czele ${ }^{42}$, z drugiej zaś wprost wyłączono możliwość rozpoznawania sprawa szkockich przez sądy kanclerskie, Queen's Bench czy Common Pleas ${ }^{43}$.

Wskazane artykuły traktatu zjednoczeniowego nie regulują kwestii uprawnień Izby Lordów do rozpoznawania spraw szkockich w drodze odwołania ${ }^{44}$. C.A Malcolm zwraca uwagę, że część Szkotów właśnie z tego powodu postrzega jurysdykcję apelacyjną Izby Lordów jako naruszenie wolności szkockich obywateli ${ }^{45}$.

38 A. Page, op. cit., s. 270-273.

39 Ibidem, s. 270.

40 Ibidem, s. 271-272.

41 Art. XVIII. „That the Laws concerning Regulation of Trade, Customs and such Excises to which Scotland is by virtue of this Treaty to be lyable be the same in Scotland from and after the Union as in England and that all other Lawes in use within the Kingdom of Scotland do after the Union and notwithstanding thereof remain in the same force as before (except such as are contrary to or inconsistent with this Treaty) but alterable by the Parliament of Great Britain With this difference betwixt the Laws concerning publick Right, Policy and Civil Government and those which concern private Right That the Laws which concern publick Right Policy and Civil Government may be made the same throughout the whole United Kingdom but that no alteration be made in Laws which concern private Right except for evident utility of the subjects within Scotland".

42 Art. XIX. „That the Court of Session or College of Justice do, after the Union, and notwithstanding thereof, remain in all time coming within Scotland as it is now constituted by the laws of that kingdom, and with the same authority and privileges as before the Union, .[...] subject nevertheless to such regulations for the better administration of justice as shall be made by the Parliament of Great Britain".

43 Art. XIX. „That no causes in Scotland be cognoscible by the Courts of Chancery, Queen's Bench, Common Pleas, or any other Court in Westminster Hall, and that the said Courts, or any other of the like nature after the Union, shall have no power to cognosce, review, or alter the acts or sentences of the judicature within Scotland, or stop the execution of the same".

44 C.A. Malcolm, op. cit., s. 298.

45 Ibidem, s. 295. 
Część komentatorów sceny politycznej uznawała powyższą lukę za intencjonalne działania angielskich komentatorów, którzy uznawali za korzystne posiadanie jednego brytyjskiego sądu najwyższego w postaci Izby Lordów, a uregulowanie tej kwestii wprost w traktacie zjednoczeniowym mogłoby być nie do zaakceptowania przez Szkotów i doprowadzić do jego odrzucenia ${ }^{46}$. Z kolei szkoccy negocjatorzy mieli zakładać, że takie apelacje ze względu na koszt i długotrwałość nie będą się cieszyć zainteresowaniem, a strony zaakceptują wyrok Sądu Sesji ${ }^{47}$. Drugie stanowisko mówi o nieuregulowaniu kwestii apelacji od wyroków Sądu Sesji do Izby Lordów z powodu braku woli wprowadzenia takiego rozwiązania, a jego faktyczne zaistnienie jest postrzegane jako uzurpacja jurysdykcji odwoławczej. To stanowisko wynika z samej treści traktatu zjednoczeniowego, który zakłada ochronę szkockiego porządku prawnego, a kierowanie skarg do sądu, który nie ma wiedzy oraz praktyki w owym porządku, stanowiło bardzo realne zagrożenie jego wypaczenia ${ }^{48}$.

\section{ODWOŁANIA OD WYROKÓW SĄDU SESJI DO BRYTYJSKIEJ IZBY LORDÓW}

Opisana luka — bez względu, czy była efektem celowego zabiegu, czy niedopatrzenia — musiała zostać zweryfikowana w praktyce. Początkowo uważano, że apelacje do Londynu nie staną się popularną metodą kwestionowania orzeczeń Sądu Sesji ze względu na czas ich rozpoznawania oraz koszt (zarówno samej sprawy, jak i podróży do stolicy $)^{49}$.

Odpowiednio 21 i 24 lutego 1708 roku dwóch pierwszych skarżących poinformowało Sąd Sesji o wniesieniu odwołania od jego wyroków do brytyjskiego parlamentu ${ }^{50}$, jednak pierwszą szkocką sprawą, która została rozpoznana przez Izbę Lordów, była sprawa Rosebery vs. Inglis wniesiona na wyrok Sądu Sesji jeszcze sprzed unii. Sprawa nie doczekała się rozstrzygnięcia w trakcie obrad pierwszego parlamentu, drugi zaś oddalił skargę. Co jednak istotne — przyjęcie skargi oznaczało przejęcie (a dla niektórych — uzurpację ${ }^{51}$ ) przez Izbę Lordów uprawnień dawnego szkockiego parlamentu ${ }^{52}$.

\footnotetext{
46 A.J. MacLean, op. cit., s. 52.

47 G. Dymond, op. cit., s. 4.

48 A.J. MacLean, op. cit., s. 52.

49 Ibidem, s. 69.

50 Ibidem, s. 51.
}

51 Tak oceniali go generalnie szkoccy sędziowie, w szczególności najbardziej zasłużeni z sędziów Sądu Sesji w osobach Lorda Staira oraz Lorda Fountainhalla. Ten ostatni, wskazując na trzynaście apelacji wniesionych w 1711 roku, stwierdza, że są to działania na szkodę narodu. C.A. Malcolm, op. cit., s. 300.

52 T. Beven, Appellate jurisdiction of the House of Lords II..., s. 363. 
Od samego początku apelacje od wyroków Sądu Sesji nabrały nowego charakteru, który zaważył na ich nieprzewidzianej popularności wśród Szkotów. W odróżnieniu od dawnych odwołań do szkockiego parlamentu przyjęcie apelacji do rozpoznania przez Izbę Lordów niosło za sobą zawieszenie wykonania wyroku szkockiego sądu ${ }^{53}$. Odwołujący widzieli w nowym środku zaskarżenia w głównej mierze mechanizm opóźniający — czasami o lata - spełnienie zasądzonego świadczenia ${ }^{54}$. Doprowadziło to niemalże do kompletnego sparaliżowania działalności orzeczniczej Izby Lordów w drugiej połowie XVIII wieku ${ }^{55}$.

Modyfikacja tego rozwiązania nastąpiła w 1808 roku w związku z reformą Sądu Sesji i wprowadzeniem w nim wewnętrznego podziału na Izby. W nowym stanie prawnym apelacja przysługiwała jedynie od orzeczenia Izby odwoławczej (Inner Chamber) ${ }^{56}$. Nie miała już cechy automatycznej suspensywności wstrzymanie wykonalności pozostawiono w gestii składu odwoławczego. O tym, jak bardzo obniżyło to popularność odwołań, najlepiej świadczy fakt, iż w okresie pierwszych stu lat (1708-1808) zanotowano ponad 300 spraw $^{57}$, kolejne zaś sto lat takich odwołań przyniosło jedynie cztery ${ }^{58}$. Popularność tych odwołań w ocenie części szkockich polityków i prawników kwestionowała prestiż najważniejszego szkockiego sądu' ${ }^{59}$.

Duże wątpliwości budziła kompetencja sędziów mających rozstrzygać odwołania od wyroków szkockich sądów, którzy wykształceni byli w anglosaskiej tradycji prawnej ${ }^{60}$. Postulowano, aby za każdym razem w składzie orzekającym zasiadał przynajmniej jeden prawnik o uznanej wiedzy i praktyce w szkockim systemie prawnym ${ }^{61}$. Co ciekawe, jego rola miała się nie ograniczać do udziału jedynie w sprawach szkockich, ale także w tych, które dotyczyły odwołań od sądów angielskich i kolonialnych ${ }^{62}$. Równocześnie zastosowanie takiego rozwiązania budziło obawę, że ten system wypaczy idee kolegialności rozstrzygania sporu

53 Co ciekawe, mechanizm suspensywności automatycznej dotyczy jedynie odwołań od szkockich orzeczeń - w przypadku odwołań od wyroków sądów angielskich i irlandzki dopiero skład orzekający mógł zadecydować w poszczególnej sprawie o wstrzymaniu wykonalności zaskarżonego orzeczenia. T. Beven, Appellate Jurisdiction of the House of Lords II..., s. 363.

${ }^{54}$ C.A. Malcolm, op. cit., s. 300.

55 T. Beven, Appellate jurisdiction of the House of Lords II..., s. 363.

56 C.A. Malcolm, op. cit., s. 301.

57 J. Finley podaje nawet większą liczbę 552 apelacji wniesionych między 1709 a 1800 rokiem. J. Finlay, Scots lawyers and House of Lords appeals in eighteenth-century Britain, „Journal of Legal History" 2011, nr 3, s. 253.

58 T. Beven, Appellate jurisdiction of the House of Lords II..., s. 363.

59 J. Finlay, op. cit., s. 249.

60 Trzeba jednak wskazać, że podobne zarzuty odnoszono w związku z odwołaniami od wyroków sądów angielskich i irlandzkich względem szkockich parów. A.J. MacLean, op. cit., s. 50.

${ }^{61}$ C.A. Malcolm, op. cit., s. 302.

62 Tu wypada przypomnieć, że historyczne źródła systemów prawnych brytyjskich posiadłości kolonialnych są bardzo różnorodne — bazowały na elementach prawa islamu, hinduizmu (Indie), prawa francuskiego zarówno w formie Kodeksu Napoleona (Mauritius), jak i zwyczaju paryskiego 
— z jednej strony wymuszał on minimum kompetencji, z drugiej zaś groził dużym wpływem specjalisty na pozostałą część składu orzekającego ${ }^{63}$.

W ten sposób Izba Lordów na początku XVIII wieku uzyskała bardzo szeroką jurysdykcję odwoławczą — rozpoznawała odwołania od wyroków sądów kanclerskich, Sądu Szachownicy, Queen's Bench, irlandzkiej Izby Szachownicy oraz szkockiego Sądu Sesji ${ }^{64}$. Od początku XIX wieku mechanizm sądu parlamentarnego okazywał się coraz bardziej niewydolny. Postulowano utworzenie stałego Sądu Najwyższego jako instytucji odrębnej od Izby Lordów ze stałym składem i profesjonalnym aparatem urzędniczym. Równocześnie postulowano ograniczenie możliwości występowania przed tym sądem jedynie dla najbardziej doświadczonych profesjonalnych pełnomocników ${ }^{65}$.

W drugiej połowie XIX wieku brytyjski sąd parlamentarny doczekał się wielu reform. W 1856 roku w ramach Izby Lordów wyodrębniono komitet orzeczniczy, w skład którego wchodzili lordowie o prawniczym wykształceniu, którym powierzono rozpoznawanie odwołań ${ }^{66}$.

Przejściowe zmiany wprowadzono ustawą z 1873 roku $^{67}$, która odebrała jurysdykcję odwoławczą Izbie Lordów i powołała w jej miejsce nowy Sąd Apelacyjny (Court of Appeals). Reforma ta okazała się krótkotrwała i już ustawą z 1876 roku $^{68}$ przywrócono Izbie Lordów uprawnienia sądownicze ${ }^{69}$. Ustawa dodatkowo uregulowała wymogi stawiane lordom sądowym oraz zakres ich uprawnieńn ${ }^{70}$.

Uprawnienia do wnoszenia apelacji do Izby Lordów zostały znacząco ograniczone przez ustawę z 1934 roku $^{71}$, która wprowadziła wymóg uzyskania zgody sądu apelacyjnego na wniesienie apelacji lub zgody komisji apelacyjnej (Appeal Committe) Izby Lordów na jej przyjęcie ${ }^{72}$.

(St. Lucia), prawa rzymsko-holenderskiego (Cejlon oraz obecna Republika Południowej Afryki) oraz hiszpańskiego (Tobago i Trynidad). The supreme..., s. 155.

63 Ibidem, s. 160.

64 Ibidem, s. 154.

65 Ibidem, s. 161

66 C.A. Malcolm, op. cit., s. 301.

67 Supreme Court of Justice Bill z 1873 roku.

68 The Appellate Jurisdiction Act z 1876 roku.

${ }^{69}$ G. Drewry, One appeal too many? Ananalys is of the functions of the House of Lords as a final court of appeal, „The British Journal of Sociology” 1968, nr 4, s. 445-446.

70 Skład izby Lordów został uzupełniony o (początkowo) czterech, a następnie dziewięciu Lordów sądowych, którymi mogły zostać osoby odznaczające się wybitną wiedzą oraz praktyką prawną nie krótszą niż piętnaście lat w angielskiej, szkockiej lub irlandzkiej palestrze. Lordowie otrzymywali wynagrodzenie w kwocie 6000 funtów rocznie i uzyskiwali status baronów, który jednak nie miał charakteru dziedzicznego. Sędziowie, którzy przeszli w stan spoczynku, zachowywali prawo do zasiadania w Izbie Lordów. C.A. Malcolm, op. cit., s. 303-304.

71 Administration of Justice (Appeals) Act z 1934 roku.

72 G. Drewry, op. cit., s. 447. 


\section{ZAKOŃCZENIE}

Powstanie Zjednoczonego Królestwa stało się dla Szkotów źródłem zarówno szans, jak i obaw. Stali się częścią największej potęgi kolonialnej, jednocześnie ich kultura i system prawny musiały się nieustannie bronić przed anglicyzacją. W efekcie unii po raz pierwszy duża grupa Szkotów osiedliła się w Londynie - część w celach podjęcia pracy bądź funkcji w organach centralnych, część zaś dla podjęcia działalności gospodarczej w ówczesnym biznesowym centrum świata ${ }^{73}$. Doprowadziło to po raz pierwszy do tak bezpośredniego zderzenia prawnego — zarówno w zakresie odmiennych systemów, jak i interakcji prawników wykształconych w skrajnie odmienny sposób, co widać chociażby w sposobie argumentacji sądowej ${ }^{74}$.

Szkocki system prawny od samego początku był bardzo narażony na wpływ prawa angielskiego, ponieważ nie miał podstawowego instrumentu cementującego charakter systemu prawnego w postaci kodeksu ${ }^{75}$. Przy tym wypada zaznaczyć, że ocena prawa angielskiego nie była jednoznaczna — z jednej strony uważano je za zagrożenie rodzimego systemu prawnego, który był nie tylko regulatorem praw i obowiązkiem, ale nośnikiem istotnych tradycji i wartości społecznych. Z drugiej jednak strony doceniano prawo angielskie za jego nowoczesną konstrukcję, częstokroć bardziej przystającą do potrzeb obrotu gospodarczego ${ }^{76}$.

Próby unifikacji szkockiego i angielskiego prawa prywatnego mają zresztą długą historię. Po raz pierwszy pojawiły się w związku z unią koron z 1603 roku, lecz na drodze harmonizacji porządków prawnych stanęli nowi poddani szkockiego króla, którzy obawiali się, że model nowego systemu będzie wynikał z regulacji szkockich. Podobne działania, tym razem skierowane na upodobnienie prawa szkockiego do regulacji angielskich, postulowano zarówno w czasie dyktatury Cromwella, jak i restauracji dynastii Stuartów (w trakcie nieudanych rokowań zjednoczeniowych w 1670 roku), aby wreszcie przyjąć model ochrony obu porządków prawnych wyrażony w cytowanych artykułach traktatu zjednoczeniowego z 1707 roku $^{77}$.

Trzysta lat doświadczeń unii szkocko-angielskiej pokazuje, że jurysdykcja odwoławcza Izby Lordów nie stała się znaczącym źródłem anglicyzacji prawa szkockiego. Utrata suspensywnego charakteru odwołań znacznie obniżyła atrakcyjność tej instytucji dla Szkotów, co w sposób dobitny pokazuje, jaka była ich opinia o brytyjskim systemie sprawiedliwości - nie udawali się tam po zmianę wyroku, a jedynie po to, by jego wykonanie odwlec w czasie. Krytyczne spojrze-

73 J. Finlay, op. cit., s. 250.

74 Wśród osób, które występowały w XVIII wieku przed Izbą Lordów, w odwołaniach od wyroku Sądu Sesji najwięcej było szkockich adwokatów - 113. Źródła mówią również o 77 angielskich barristerach oraz 15 byłych szkockich adwokatach, którzy praktykowali już wyłącznie w Londynie. J. Finlay, op. cit., s. 253.

75 G. Brodie, Strictures on the appellate jurisdiction of the House of Lords, „Quarterly Journal of Jurisprudence" 1856-1857, nr 1, s. 176.

76 J. Finlay, op. cit., s. 251.

77 A.J. MacLean., op. cit., s. 67. 
nie niektórych prawników i przedstawicieli rodzimej sceny politycznej wynikało przede wszystkim z symbolicznej utraty suwerenności w wymiarze władzy sądowniczej, dlatego też Lord Prezydent Sądu Sesji z okresu rokowań zjednoczeniowych, Lord Fountainhall, sprzeciwiał się odwołaniom do Izby Lordów nie na zasadzie ich bezprawności, ale niepotrzebnego ograniczania suwerenności Szkotów ${ }^{78}$, co pozostaje szczególnie aktualne w pobrexitowej rzeczywistości.

\title{
THE ORIGINS OF THE HOUSE OF LORDS' APPELLATE JURISDICTION ON THE SCOTTISH COURTS' DECISIONS
}

\author{
Summary
}

In the paper the author attempts to present the origin and development of the appellate jurisdiction of the House of Lords. The analysis focuses on the presentation of the sources and scope of judicial powers held by the parliaments of the kingdoms that have become part of the United Kingdom. Theauthor subsequently discussed ideas behind the regulation of separate legal systems and judicatures as in the Act of Union of 1707. The final part of the analysis is a presentation of the most important aspects of the House of Lords appellate jurisdiction in the period before the establishment of the Supreme Court of the United Kingdom.

Keywords: Scots law, Court of Session, House of Lords, mixed jurisdiction

\section{BIBLIOGRAFIA}

Beven T., Appellate jurisdiction of the House of Lords, „Law Quarterly Review” 1901, nr 2.

Beven T., Appellate jurisdiction of the House of Lords II, „Law Quarterly Review” 1901, nr 4.

Blackstone W., Commentaries on the Laws of England, Londyn 1765.

Bracton H., De Legibus et Consuetudinibus Angliae, Londyn 1569.

Brodie G., Strictures on the appellate jurisdiction of the House of Lords, „Quarterly Journal of Jurisprudence" 1856-1857, nr 1.

Chalmers J., Scottish appeals and the proposed Supreme Court, „Edinburgh Law Review” 2004, nr 8. Commentaries on the Laws of England, Londyn 1765, księga I.

De Legibus et Consuetudinibus Angliae, Londyn 1569, księga III.

Drewry G., One appeal too many? Ananalys is of the functions of the House of Lords as a final court of appeal, „The British Journal of Sociology” 1968, nr 4.

Dymond G., The Appelate Jurisdiction of the House of Lords, http://researchbriefings.files.parliament.uk/documents/LLN-2009-010/LLN-2009-010.pdf.

Erskine J., Principles of the Law of Scotland, Edinburgh 1816.

Evans-Jones R., Receptions of Law, mixed legal systems and the myth of the genius of scots private Law, „Law Quarterly Review” 1998, nr 114.

Finlay J., Scots lawyers and House of Lords appeals in eighteenth-century Britain, „Journal of Legal History" 2011, nr 3.

78 Ibidem, s. 61.

Przegląd Prawa i Administracji CXX, 2020, cz. 1 i 2

(C) for this edition by CNS 
Glanvill R., Tractatus de legibus et conseutudinibus regni Angliae, Londyn 1188.

Glover A.G., The constitutional position of the House of Lords, „Law Magazine and Review: A Quarterly Review of Jurisprudence" 1907, nr 2.

MacDouall A., Lord Bankton, An Institute of the Laws of Scotland, Edinburgh 1753.

MacLean A.J., The 1707 union: Scots law and the house of lords, „The Journal of Legal History” $1984, \mathrm{nr} 4$.

Malcolm C.A., House of Lords and appeals form Scotland, „Juridical Review” 1910-1911, nr 4.

Örücü E., Judge and jurist in Scotland: On the verge of a second renaissance, „Tulane Law Review” 2003-2004, nr 78.

Page A., Final appellate jurisdiction in the Scottish legal system: The end of the anomaly, „Edinburgh Law Review” 2010, nr 2.

Plessis P. du, The promises and pitfalls of mixed legal systems: the South African and Scottish experiences, „Stellenbosch Law Review” 1998, nr 338.

Reid K., Zimmermann R., A History of Private Law in Scotland: Introduction and property, Oxford 2000.

The supreme appellate jurisdiction, „Monthly Law Magazine” 1841, nr 39.

Tetley W., Mixed jurisdictions: Common law v. Civil law (codified and uncodified), „Louisiana Law Review" 2000, nr 3.

\section{ŹRÓDŁA INTERNETOWE}

http://www.legislation.gov.uk/ukpga/2005/4/contents (dostęp: 4.02.2020).

http://www.legislation.gov.uk/aosp/1707/7/contents (dostęp: 4.02.2020).

http://www.legislation.gov.uk/aosp/1689/28/contents (dostęp: 4.02.2020). 